\title{
Longitudinal use of feeding resources and distribution of fish trophic guilds in a coastal Atlantic stream, southern Brazil
}

\author{
Luciano Lazzarini Wolff, Natália Carniatto and Norma Segatti Hahn
}

This study described the use of food resources and the distribution of fish trophic guilds along the longitudinal gradient of a coastal Atlantic stream, southern Brazil. Allochthonous resources (terrestrial insects) predominated in the headwaters, whereas autochthonous food items (algae, fish) and detritus predominated in the mouth section. Detritivorous, aquaticinvertivorous, and terrestrial- and aquatic-insectivorous species occurred throughout the gradient, while omnivorous and piscivorous in the headwaters and middle stretches, respectively, and herbivorous in the middle and mouth. Detritivores and aquatic-insectivores were significantly more specialized than the other guilds, however, there was no evidence of a longitudinal increase in trophic specialization. Density and biomass of aquatic-invertivores and aquatic-insectivores decreased, whereas that of detritivores increased longitudinally. The distribution of trophic guilds was significantly associated with the stream section, where aquatic and terrestrial insectivorous were more frequent in rocky and flowed stretches from the headwater and detritivores in deeper environments with finer particles of substrate from the mouth. This suggests that fish assemblages in coastal streams with a steep longitudinal gradient may follow patterns in the use of food resources according with the food availability along the river, as predicted by the River Continuum Concept.

Este estudo descreve o uso dos recursos alimentares e a distribuição das guildas tróficas de peixes ao longo do gradiente longitudinal de um riacho da encosta Atlântica, Sul do Brasil. Recursos alóctones (insetos terrestres) foram consumidos com maior frequência na cabeceira, entretanto, recursos de origem autóctone (algas, peixes) e detritos foram mais frequentemente registrados na foz. Espécies detritívoras, invertívoras aquáticas, insetívoras terrestres e aquáticas ocorreram ao longo de todo gradiente, enquanto que as onívoras e piscívoras na cabeceira e meio, respectivamente, e herbívoras no meio e foz. Detritívoras e insetívoras aquáticas foram significativamente mais especializadas em relação às demais guildas; entretanto, não houve nenhuma evidência de aumento longitudinal da especialização trófica. A densidade e a biomassa de invertívoras e insetívoras aquáticas diminuíram, enquanto que das detritívoras aumentaram no sentido cabeceira-foz. A distribuição das guildas tróficas foi significativamente associada com a secção do riacho, onde insetívoras aquáticas e terrestres foram mais frequentes em trechos rochosos e de elevado fluxo da cabeceira, enquanto que detritívoras em ambientes mais profundos com partículas finas de substrato da foz. Tais resultados sugerem que assembleias de peixes de riachos tropicais de encosta, os quais apresentam acentuado gradiente longitudinal, podem seguir padrões de uso dos recursos alimentares de acordo com a disponibilidade alimentar ao longo do rio, como previstos no Conceito de Continuidade de Rios.

Key words: Atlantic Rainforest, Food availability, Freshwater fish, River Continuum Concept, Trophic structure.

\section{Introduction}

Longitudinal patterns in richness and composition of trophic guilds of stream fish and macroinvertebrate assemblages have been consistently documented along size continuum of rivers (Ibanez et al., 2007), what have leave some authors to stress about possible mechanistic processes spatial for the structuring and functioning of aquatic communities (Vannote et al., 1980; Ward, 1989; Junk et al., 1989; Rice et al., 2001; Brenden et al., 2008). These patterns are usually attributed to changes in physical conditions of streams or rivers from upstream to downstream areas creating strong constraints on assemblage structure linked to food availability (the River Continuum Concept - RCC; Vannote et al., 1980).

In this way, the composition of trophic groups of the aquatic communities would be primary structured according to the gradient produced by the variation in physical and biotic parameters (e.g., discharge, channel width, vegetation cover) and by the input/processing ratio of organic matter and primary productivity along the system (Vannote et al., 1980). Although

Universidade Estadual de Maringá (UEM), Programa de Pós-Graduação em Ecologia de Ambientes Aquáticos Continentais, Laboratório de Ecologia Trófica de Peixes. Av. Colombo, 5790, Bloco G90, Campus Universitário, 87020-000 Maringá, Paraná, Brazil. 
these predictions initially referred to communities of aquatic macroinvertebrates from temperate regions, some investigators have found similar patterns for the longitudinal distribution of fish trophic guilds, in both temperate (Schlosser, 1982; Oberdorff et al., 1993) and tropical regions (Angermeier \& Karr, 1983; Pouilly et al., 2006; Ibanez et al., 2007). These patterns are mostly explained by the longitudinal supply of food resources, which allows predictions of the trophic status of communities as a function of their longitudinal patterns of distribution (PeresNeto et al., 1995).

Although the RCC was widely discussed in freshwater ecology in the 1980s and is currently debated by different research groups, its predictions and applicability to water systems, especially tropical ones, have been extensively criticized (Poole, 2002; Melles et al., 2012). Some authors have considered the longitudinal profile of rivers as discrete zones rather than a functional-trophic continuum (Statzner \& Higler, 1986; Petry \& Schulz, 2006; Ferreira \& Petrere Jr., 2009). Nevertheless, when considering the feeding ecology and the distribution of fish trophic guilds, some studies, based on differences between the input of allochthonous matter and autochthonous productivity, have found, like a continuous, proportional changes from generalist (e.g., insectivores) to more specialized guilds (e.g., detritivores, planktivores and piscivores) along longitudinal gradients (Schlosser, 1982; Angermeier \& Karr, 1983; Pouilly et al., 2006). These results has led the authors to expect that fish assemblages in the headwaters are more dependent on allochthonous food resources such as seeds, fruits, and insects; while assemblages in downstream stretches are more dependent on autochthonous sources such as detritus, algae, macrophytes, and other fish (Vannote et al., 1980; Peres-Neto et al., 1995).

Streams along the Brazilian Atlantic coast are relatively small water bodies that course over steep slopes, where environmental conditions and the supply of food resources may be highly variable longitudinally (Aranha \& Caramaschi, 1999; Lowe-McConnell, 1999). Species composing the fish assemblages of these systems have variable feeding tactics and no significant trophic specializations (Esteves \& Aranha, 1999), which allows them wide feeding flexibility (Abelha et al., 2001). Moreover, some evidence indicates that individual species with a wide distribution along the river might shift their diets according to the spatial availability of food resources (Mazzoni \& Rezende, 2003; Rezende \& Mazzoni, 2006; Abilhoa et al., 2009; Mazzoni et al., 2010). Thus, these contents allow us to investigate longitudinal patterns of trophic structure, having as background the assumptions of the RCC.

The goal of this study was to describe the patterns in the use of food resources and the distribution of fish trophic guilds along the longitudinal gradient of a Brazilian Atlantic coast stream. We sought to answer the following questions: (i) do the use of food resources by fish and the formation of trophic guilds follow the patterns of longitudinal availability predicted by the RCC, i.e., with greater exploitation of allochthonous resources in the headwaters and autochthonous resources near the mouth? (ii) does the distribution of trophic guilds, estimated through the species composition, density and biomass, change proportionally from generalist species in the headwaters to specialist species near the mouth? and (iii) is the guild distribution associated with by variations in environmental parameters along the stream course?

\section{Material and Methods}

\section{Study area}

This study was conducted in the Vermelho River, in the eastern Atlantic basin of Brazil (Fig. 1). This river lies within the boundaries of the newly established "Reserva Particular do Patrimônio Natural" (RPPN) Morro da Mina, between the coastal municipalities of Antonina and Morretes in the state of Paraná, southern Brazil. The Vermelho River rises in the mountainous part of the reserve and flows into the Xaxim River, which in turn connects the river basin network to Antonina Bay.

The Vermelho River is a third-order stream according to the classification of Strahler (Allan, 1995). It is typical of the Atlantic Forest: small, approximately $3 \mathrm{~km}$ long, with a steep slope, relatively narrow, with stretches of riffles alternating with backwaters and shallow pools. The water is relatively cold, and the bottom is composed predominantly of boulders and gravel upstream and sand and leaf litter downstream (personal observation).

The climate is type Af according to Koeppen (Maack, 1981), a transitional tropical climate, with mean temperature in the coldest month above $18^{\circ} \mathrm{C}$ and annual rainfall varying between 2,500 and 3,000 $\mathrm{mm}$. According to Velloso et al. (1991), the main vegetation types are: pioneer formations of fluvialmarine influence (mangroves and restinga vegetation) and inland influence (swamps and wetlands) in the lowland areas, and submontane and alluvial Dense Ombrophilous Forest in the highland areas.

\section{Sampling sections}

Three sections were sampled in the Vermelho River, each $50 \mathrm{~m}$ long, as follows: Headwaters $\left(25^{\circ} 21^{\prime} 54.12^{\prime \prime} \mathrm{S}\right.$ $48^{\circ} 49^{\prime} 55.56^{\prime} \mathrm{W}$, elevation $160 \mathrm{~m}$ ), with a predominance of riffles, rocky bottom (solid rock and boulders) and dense vegetation cover; Middle (2521'45.12”S 4849'35.58”W, elevation 80 m), intermediate stretch characterized by moderate-flow rapids and areas with backwaters and pools, with a predominance of sandy/rocky substrate and dense/moderate vegetation cover; and Mouth (25'21'42.72”'S 48 48'56.34”'W, elevation 40 m) characterized by backwaters and pools, with a predominance of sandy/clayey bottom and moderate vegetation cover.

\section{Fish collection}

Fish were collected by electrofishing every three months from May 2009 to February 2010, using a TOYAMA ${ }^{\circledR}$ power generator, with 127 Volts AC and $5 \mathrm{~A}$. Short stretches were sampled within each sampling section, from eight to $13 \mathrm{~m}$ long, which were blocked with seines (3-mm mesh) to prevent the fish from escaping. The catch was made using three 


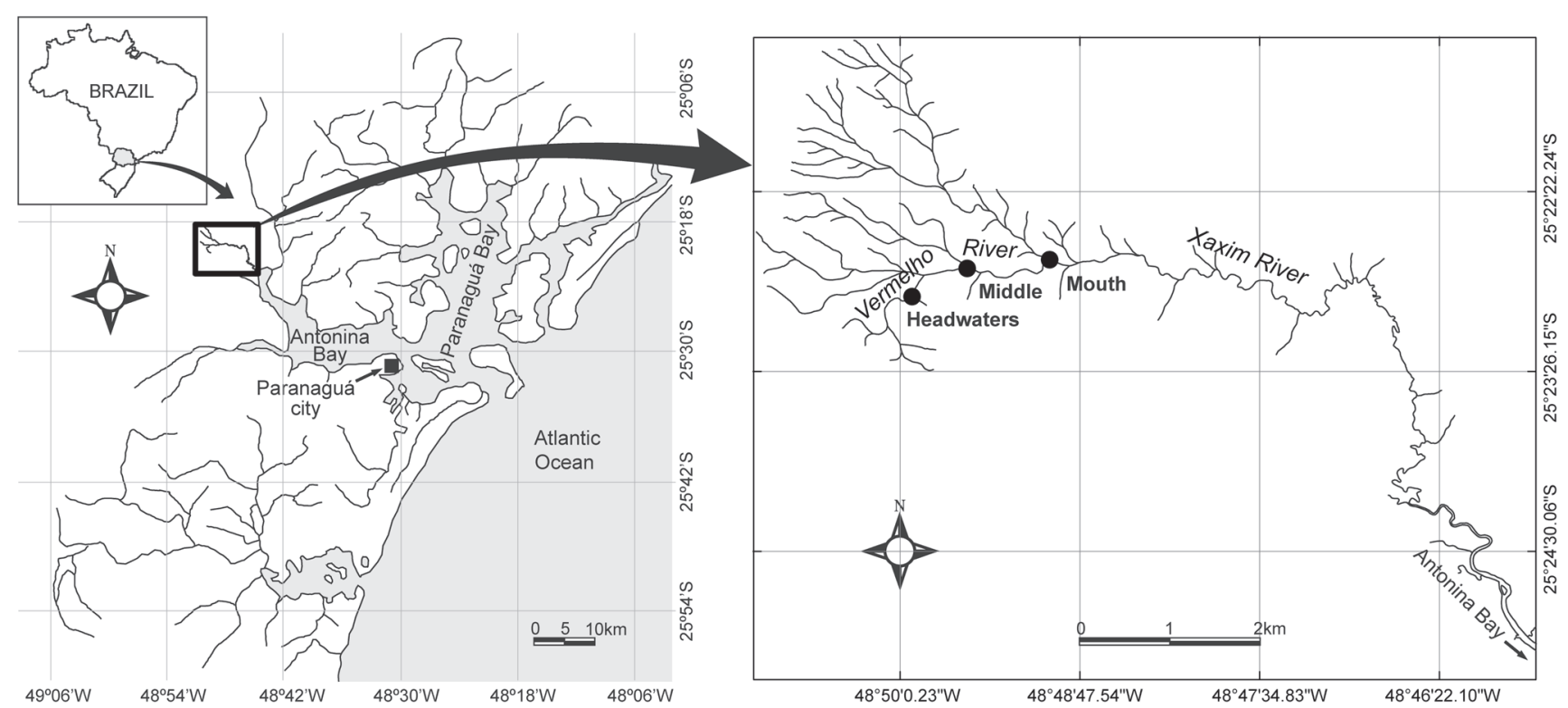

Fig. 1. Location of the Vermelho River, East Atlantic basin, Antonina, Paraná State, Brazil. Black circles indicate the sampling sections; arrow indicates the direction of flow.

successive passes of electrodes and dip nets in each stretch, and the samples included the individuals captured by the dip nets and those caught in the seines. Fish were euthanized with $10 \%$ benzocaine and then fixed in $10 \%$ formaldehyde. In the laboratory, specimens were identified, counted, weighed, measured, and gutted to remove the gastrointestinal tract. Voucher species were deposited in the Nupélia Ichthyological Collection of the State University of Maringá (voucher specimens are listed in Table 3).

\section{Environmental variables}

Hydrological and structural data were obtained in each sampling stretch where fish were caught. Hydrological data included the water temperature $\left({ }^{\circ} \mathrm{C}\right)$, measured with a mercury thermometer; dissolved oxygen (mg.l"1), with a digital oximeter $\left(\mathrm{YSI}^{\circledR} 550 \mathrm{~A}\right)$; and $\mathrm{pH}$ and electrical conductivity $\left(\mu \mathrm{S} . \mathrm{cm}^{-1}\right)$, with a digital potentiometer $\left(\right.$ Digimed $\left.^{\circledR}\right)$. The water velocity $\left(\mathrm{m} . \mathrm{s}^{\mathrm{\prime \prime}}\right)$, measured with a mechanical flowmeter (General Oceanics $^{\circledR}$ ), was determined from the arithmetic mean of three observations for each stretch. The mean depth $(\mathrm{cm})$ was determined through five equidistant measurements along the transverse axis of the stream, at the same points where the water velocity was recorded. The channel width (m) was taken along the same transverse axis where the depth was estimated, and was determined as the arithmetic mean of three observations.

The different categories of substrate were quantified by visual inspection, by establishing a relative percentage for each. Size classes were based on Gordon et al. (1992): rocks (solid rock), boulders ( $>80 \mathrm{~mm}$ diameter), pebbles (25 - 50 $\mathrm{mm}$ ), gravel $(5-15 \mathrm{~mm})$, sand $(<15 \mathrm{~mm}$ ), and sand/clay (mixture of sand with silt particles). Other structures including tree trunks/branches, macroalgae and leaf litter were also quantified.

\section{Diet analysis}

The contents of the stomach and intestine were examined under stereoscopic and optical microscopes, and the food items were identified to the lowest possible taxonomic level. To evaluate the contribution of each item in the diet, the volumetric frequency was employed (Hyslop, 1980), in which the volume of each item is recorded, obtaining the percentage in relation to the total value of each stomach content. The volume was obtained in two ways: by the displacement of the water column, using a set of graduated cylinders, when the volume exceeded $0.1 \mathrm{ml}$; and with a millimeter plate, where the volume was obtained in $\mathrm{mm}^{3}$ and later transformed into $\mathrm{ml}$, for volumes less than $0.1 \mathrm{ml}$ (Hellawel \& Abel, 1971). For detritivorous species, the food in the first third of the intestine was removed and estimated as for its total volume on a millimeter plate, and analyzed under an optical microscope. The amount of microscopic items (e.g., algae, detritus, and sediment) was estimated visually and transformed into percentage volume $(\mathrm{ml})$. The food items were grouped into the following categories: aquatic insects (larvae of Diptera such as Chironomidae and Simulidae, Coleoptera, Ephemeroptera, Trichoptera, and Plecoptera, nymphs of Odonata, and aquatic Hemiptera such as Belostomatidae and Corixiidae), terrestrial insects (adults of Coleoptera, Diptera, Trichoptera, Orthoptera, Lepidoptera, Blattaria, Homoptera, and Hymenoptera), other terrestrial invertebrates, other aquatic invertebrates, fish, plant, algae, and detritus/sediment. 


\section{Data analysis}

Patterns of environmental variability between sampling sections (headwaters, middle and mouth) were identified by a principal components analysis (PCA), applied on the matrix of Pearson correlation of abiotic variables. The variables were standardized by the square root of the sum of their squares, to minimize the differences in the measurement scale. The criterion adopted to retain and interpret the axes (principal components) was the BrokenStick model, in which only the axes with eigenvalues higher than those generated at random are interpreted.

In order to characterize the trophic guilds, a detrended correspondence analysis (DCA; Hill \& Gauch, 1980) was applied to the matrix of percentage volume of food items. The DCA is a multivariate analysis that allows the ordination of species and food items onto the multivariate space, and the resulting scatterplot facilitates the interpretation of the food gradient. The guilds were defined as detritivores (when detritus/sediment was predominant), herbivores (when plant items such as leaf fragments and seed/fruit predominated), omnivores (when the amounts of plants and other food animal categories were similar), aquatic-insectivores (when aquatic insects such as larvae and nymphs of Ephemeroptera, Trichoptera, Chironomidae, and Odonata predominated), terrestrial-insectivores (when terrestrial insects, including those with aquatic stages such as Diptera, Coleoptera, Hymenoptera and Lepidoptera predominated), aquaticinvertivores (when other aquatic invertebrates such as crabs and shrimps predominated) and piscivores (when fish predominated).

In order to show the relative level of dietary specialization and to associate this with the longitudinal gradient, the diet breadth of the species or guilds was calculated, with volume data, for the samples from each section, using Levin's standardized index $(B)$ :

$$
B i=\frac{1}{(n-1)}\left(\frac{1}{\left(\sum_{j} p_{i j}^{2}\right)}-1\right)
$$

where: $B i=$ Levin's standardized index for predator $i ; p_{i j}=$ proportion of diet of predator $i$ that is made up of prey $j ; n=$ total number of food resources (Hurlbert, 1978). This index ranges from 0 (diet specialized in few prey items) to 1 (generalist diet). The data for diet breadth of the guilds were tested by ANOVA, recognizing the assumptions of normality and equality of variance.

For the analysis of longitudinal distribution, the species composition of trophic guilds was defined as the relative number of species in each guild. These values were tested by a contingency test based on the $\chi^{2}$ distribution (Zar, 1999), to check for possible significant associations with the sampling sections. This analysis was performed in the application PAST 2.08 (Paleontological Statistic Software), and the statistical significance of $\mathrm{p}$ was calculated by a permutation test with 9999 replicates (Hammer et al., 2001). The sampling section was considered as the independent variable (predictor) and the species composition of the guilds as the dependent variable (response). Based on the volume data of the stream section where the fish were sampled and for the weight of individual fish, the values of density (number of individuals/ $\mathrm{m}^{3}$ ) and biomass (grams of fish $/ \mathrm{m}^{3}$ ), respectively, of the trophic guilds were determined.

In order to evaluate the relationship of guilds distribution to the environmental gradient of the stream, Spearman correlations $\alpha=(0.05)$ were run between the scores from the first PCA axis applied on the correlation matrix between the environmental variables and the values for species composition of the trophic guilds. This analysis was performed only for those guilds that occurred throughout the stream. The multivariate analysis was performed in the software PC-ORD 5.10, while the scatterplots, Spearman correlations and ANOVA were calculated with the software Statistica 7.0.

\section{Results}

\section{Abiotic gradient}

The water temperature and dissolved oxygen varied little along the gradient, while the $\mathrm{pH}$ and conductivity were slightly lower in the mouth section (Table 1). The water velocity was greater in the headwaters, and the depth and channel width in the mouth section. With respect to the substrate composition, boulders and cobbles predominated in the headwaters, cobbles and gravel in the middle, and sand/clay and wood in the mouth section (Table 1).

The first three axes of the principal components analysis explained $74.8 \%$ of total data variability (Fig. 2; Table 2). The PCA1 described a longitudinal gradient separating the headwaters with negative scores (predominantly rocky, with high water velocity and $\mathrm{pH}$ tending to neutrality) from the middle section, with intermediate scores; and from the mouth,

Table 1. Mean \pm standard deviation of hydrological parameters and substrate composition variables along the headwatersmouth gradient of the Vermelho River, East Atlantic basin, Antonina, Paraná State, Brazil.

\begin{tabular}{lcccccc}
\hline & \multicolumn{3}{c}{ Headwaters } & \multicolumn{2}{c}{ Middle } & \multicolumn{2}{c}{ Mouth } \\
\hline Water temperature $\left({ }^{\circ} \mathrm{C}\right)$ & 20.0 & $(2.4)$ & 20.6 & $(2.3)$ & 20.5 & $(3.3)$ \\
Dissolved oxygen $\left(\mathrm{mg} .1^{-1}\right)$ & 7.7 & $(1.2)$ & 7.5 & $(0.5)$ & 7.5 & $(1.0)$ \\
pH & 7.2 & $(0.4)$ & 7.0 & $(0.4)$ & 6.5 & $(0.4)$ \\
Conductivity $\left(\mu \mathrm{S.cm}^{-1}\right)$ & 42.6 & $(2.3)$ & 39.6 & $(3.9)$ & 38.4 & $(3.5)$ \\
Water velocity $\left(\mathrm{m} .^{-1}\right)$ & 5.9 & $(0.6)$ & 3.1 & $(1.4)$ & 2.6 & $(0.7)$ \\
Depth $(\mathrm{cm})$ & 17.5 & $(4.1)$ & 20.5 & $(2.7)$ & 35.8 & $(21.9)$ \\
Channel width (m) & 3.2 & $(0.5)$ & 2.9 & $(0.1)$ & 4.5 & $(0.8)$ \\
& Substrate composition & & & \\
Boulders (\%) & 50.9 & $(2.8)$ & 2.1 & $(3.1)$ & 0.0 & $(0.0)$ \\
Cobbles (\%) & 29.1 & $(4.5)$ & 27.9 & $(4.9)$ & 0.0 & $(0.0)$ \\
Pebbles (\%) & 7.8 & $(3.3)$ & 24.2 & $(3.0)$ & 7.1 & $(9.1)$ \\
Gravel (\%) & 12.2 & $(5.6)$ & 31.3 & $(4.2)$ & 8.8 & $(6.4)$ \\
Sand (\%) & 0.0 & $(0.0)$ & 0.6 & $(0.8)$ & 6.3 & $(7.5)$ \\
Sand/Clay (\%) & 0.0 & $(0.0)$ & 4.4 & $(2.1)$ & 33.3 & $(24.2)$ \\
Wood (\%) & 0.0 & $(0.0)$ & 2.7 & $(1.6)$ & 26.7 & $(5.4)$ \\
Leaf litter (\%) & 0.0 & $(0.0)$ & 6.9 & $(6.2)$ & 15.8 & $(10.9)$ \\
Macroalgae (\%) & 0.0 & $(0.0)$ & 0.0 & $(0.0)$ & 2.1 & $(3.2)$ \\
\hline
\end{tabular}




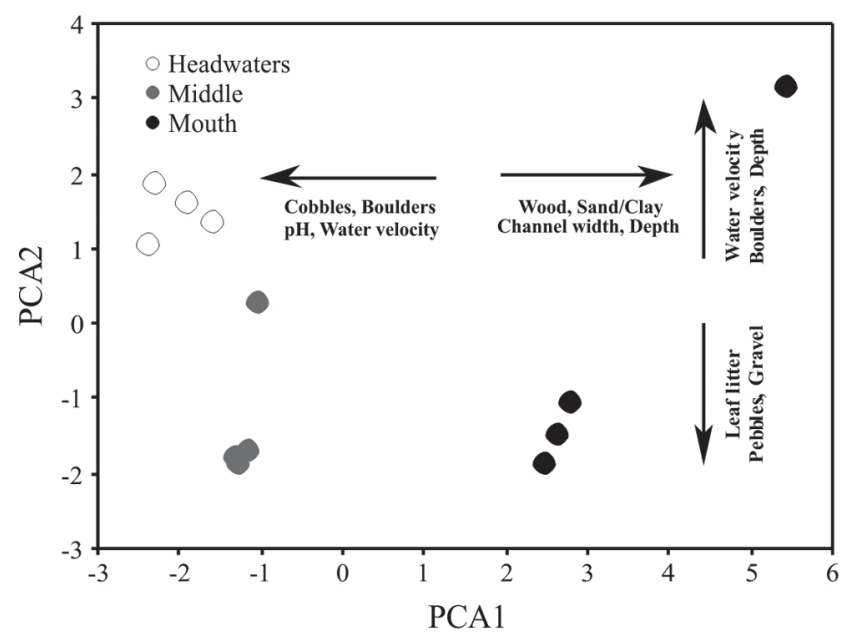

Fig. 2. Ordination of sampling sections along the environmental gradient defined by the first two axes of the principal components analysis (PCA1 and PCA2) applied to the correlation matrix of abiotic variables of the Vermelho River, East Atlantic basin, Antonina, Paraná State, Brazil.

with positive scores (substrate with finer particles, large amounts of woody debris, deeper and wider channel). The PCA2 contributed to segregate the headwaters (with rapid flow) from the middle and mouth (with larger amounts of leaf litter), but was strongly influenced by a rainfall event during the sampling in the mouth section in February 2010. In turn, the PCA3 was significant, but contributed very little to explain the environmental gradient.

\section{Diet and trophic guilds}

The fish assemblage in the Vermelho River consisted of 19 species, representing seven families and four orders (Table 3 ). We examined the stomach contents of 734 individuals: 216 (12 species) from the headwaters, 326 (15 species) from the middle and 192 (14 species) from the mouth.

The main resources consumed were aquatic and terrestrial insects, other aquatic invertebrates, and detritus/sediment. Among the allochthonous resources, terrestrial insects were ingested by nine species in the headwaters, eight in the middle, and four in the mouth, but were prominent only in the diets of Hollandichthys multifasciatus and Mimagoniates microlepis. With respect to autochthonous resources, aquatic insects were exploited by 10 species in the headwaters, 13 in the middle, and 10 in the mouth, especially in the diets of Acentronichthys leptos, Characidium lanei, Characidium pterostictum and Scleromystax barbatus in the middle; while other aquatic invertebrates predominated in the diet of three species in the headwaters (Synbranchus marmoratus, Rhamdia quelen and Rhamdioglanis frenatus), two in the middle (Rhamdia quelen and Rhamdioglanis frenatus), and three in the mouth (S. marmoratus, H. multifasciatus and Pimelodella pappenheimi. Detritus/sediment was among the
Table 2. Eigenvector, eigenvalue and variance explained by the first three axes (PCA1, PCA 2 and PCA3) with the correlation matrix of environmental variables of the Vermelho River, East Atlantic basin, Antonina, Paraná State, Brazil. Bold values indicate eigenvectors that most contributed to the axes formation.

\begin{tabular}{|c|c|c|c|}
\hline & $\mathrm{CP} 1$ & $\mathrm{CP} 2$ & CP3 \\
\hline Water temperature $\left({ }^{\circ} \mathrm{C}\right)$ & 0.073 & 0.201 & -0.361 \\
\hline Dissolved oxygen $\left(\mathrm{mg}^{-1}\right)$ & -0.087 & -0.014 & 0.326 \\
\hline $\mathrm{pH}$ & -0.286 & -0.009 & 0.094 \\
\hline Conductivity $\left(\mu \mathrm{S} . \mathrm{cm}^{-1}\right)$ & -0.220 & -0.108 & 0.371 \\
\hline Water velocity $\left(\mathrm{m} \cdot \mathrm{s}^{-1}\right)$ & -0.222 & 0.430 & 0.074 \\
\hline Depth $(\mathrm{cm})$ & 0.301 & 0.242 & -0.267 \\
\hline Channel width (m) & 0.341 & 0.195 & 0.048 \\
\hline Boulders (\%) & -0.238 & 0.350 & 0.264 \\
\hline Cobbles $(\%)$ & -0.359 & 0.101 & -0.154 \\
\hline Pebbles $(\%)$ & -0.162 & -0.364 & -0.360 \\
\hline Gravel (\%) & -0.191 & -0.343 & -0.336 \\
\hline Sand $(\%)$ & 0.166 & -0.246 & 0.118 \\
\hline Sand/Clay (\%) & 0.353 & 0.157 & -0.073 \\
\hline Wood (\%) & 0.381 & -0.023 & 0.100 \\
\hline Leaf litter $(\%)$ & 0.186 & -0.421 & 0.211 \\
\hline Macroalgae (\%) & 0.159 & -0.142 & 0.358 \\
\hline Eigenvalue & 6.65 & 3.22 & 2.10 \\
\hline Predicted eigenvalue (Broken-Stick) & 3.38 & 2.38 & 1.88 \\
\hline Explained variance (\%) & 41.6 & 20.1 & 13.1 \\
\hline
\end{tabular}

resources most exploited by the fish fauna, and was prominent in the diet of three species in the headwaters, five in the middle, and seven in the mouth (Table 3 ).

The first DCA axes (eigenvalues $=0.93,0.92$ and 0.92 for the headwaters, middle, and mouth sections, respectively) were the most informative and distinguished the species into seven trophic guilds (omnivores, detritivores, herbivores, piscivores, aquatic-invertivores, terrestrial-insectivores, and aquatic-insectivores) along the longitudinal gradient (Fig. 3).

The detritivores, consisting of the poeciliid Phalloceros harphagos and all loricariid armored catfishes, was the most diversified guild. Schizolecis guntheri was common to all sections; Ancistrus multispinnis and Schizolecis sp. 1 were common to the headwaters and to the middle, Rineloricaria sp. and P. harpagos to the middle and mouth, and Kronichthys lacerta, Pseudotothyris obtusa and Schizolecis sp. were exclusive to the mouth. Also, S. barbatus was included as detritivorous in the mouth. Except for P. harpagos in the mouth, these species showed low diet breadth values ( $B$ between 0.01 to 0.08 ), indicating a high degree of specialization on detritus/sediment (Table 3). Aquaticinsectivores occurred throughout the stream, represented by the same species in the different sections (e.g., A. leptos, $C$. lanei, $C$. pterostictum) except in the middle where $S$. barbatus was included. Their diets were dominated by larvae of aquatic insects such as Ephemeroptera and Trichoptera (up to 50\%), and showed high to intermediate specialization ( $B$ from 0.01 to 0.29 ). Aquatic-invertivores fed on decapods especially, and was the guild that changed the most in species composition. In the headwaters it was represented by $S$. marmoratus, Rhamdia quelen and Rhamdioglanis frenatus and the two latter also in the middle, whereas in the mouth it was 
Table 3. Systematic position, diet composition and breadth (Levin's index $\boldsymbol{B}$ ) of fish assemblage of the Vermelho River, East Atlantic basin, southern Brazil. Data are expressed as percentage volume of food items. Number of stomachs analyzed (N); $*=$ Values $<0.1 \% ;-$ not recorded. Predominant items are in bold.

\begin{tabular}{|c|c|c|c|c|c|c|c|c|c|c|c|c|}
\hline & & & & & Allochthonous & & & Autochthonous & & & Undetermined & \\
\hline & Code & $\begin{array}{l}\text { Voucher } \\
\text { specimen }\end{array}$ & $\mathrm{N}$ & $\begin{array}{l}\text { Terrestrial } \\
\text { insect }\end{array}$ & $\begin{array}{l}\text { Other terrestrial } \\
\text { invertebrates }\end{array}$ & Plants & $\begin{array}{l}\text { Aquatic } \\
\text { insects }\end{array}$ & $\begin{array}{l}\text { Other aquatic } \\
\text { invertebrates }\end{array}$ & Fish $A$ & Algae & $\begin{array}{l}\text { Detritus/ } \\
\text { sediment }\end{array}$ & $B$ \\
\hline Headwater & & & & & & & & & & & & \\
\hline $\begin{array}{l}\text { CHARACIFORMES } \\
\text { Characidae }\end{array}$ & & & & & & & & & & & & \\
\hline Deuterodon langei & Dlan & NUP9541 & 67 & 38.1 & 2.3 & 50.1 & 5.6 & 0.2 & - & 2.6 & 1.1 & 0.25 \\
\hline Hollandichthys multifasciatus & Hmul & NUP9529 & 5 & 98.0 & 1.7 & 0.3 & - & - & - & - & - & 0.02 \\
\hline $\begin{array}{l}\text { Mimagoniates microlepis } \\
\text { Crenuchidae }\end{array}$ & Mmic & NUP9526 & 7 & 49.3 & 11.9 & 0.1 & 38.7 & - & - & - & - & 0.49 \\
\hline Characidium lanei & Clan & NUP9528 & 40 & 0.2 & 0.2 & 0.4 & 95.0 & 2.2 & - & - & 2.1 & 0.02 \\
\hline $\begin{array}{l}\text { Characidium pterostictum } \\
\text { SILURIFORMES } \\
\text { Heptapteridae }\end{array}$ & Cpte & NUP9583 & 23 & 7.8 & - & 1.1 & 81.4 & 1.5 & - & - & 8.3 & 0.12 \\
\hline Acentronichthys leptos & Alep & NUP9569 & 14 & 9.8 & - & 12.0 & 76.5 & - & - & - & 1.7 & 0.21 \\
\hline Rhamdia quelen & Rque & NUP9524 & 5 & 8.2 & 4.8 & 15.2 & 1.5 & 70.3 & - & - & - & 0.22 \\
\hline $\begin{array}{l}\text { Rhamdioglanis frenatus } \\
\text { Loricariidae }\end{array}$ & Rfre & NUP13614 & 25 & 19.6 & 11.7 & 3.2 & 3.2 & 60.3 & - & - & 2.0 & 0.28 \\
\hline Ancistrus multispinnis & Amul & NUP13626 & 10 & - & - & ـ & - & * & - & 2.2 & 97.8 & 0.02 \\
\hline Schizolecis guntherti & Sgun & NUP9465 & 7 & - & - & - & 0.3 & - & - & 2.3 & 97.5 & 0.03 \\
\hline $\begin{array}{l}\text { Schizolecis sp. } 1 \\
\text { SYNBRANCHIFORMES } \\
\text { Synbranchidae }\end{array}$ & Schsp1 & NUP10899 & 8 & - & - & - & 0.4 & $*$ & - & 5.6 & 93.9 & 0.04 \\
\hline Synbranchus marmoratus & Smar & NUP9567 & 5 & 2.0 & - & - & 8.9 & 82.8 & 5.7 & - & 0.6 & 0.11 \\
\hline Middle & & & & & & & & & & & & \\
\hline $\begin{array}{l}\text { CHARACIFORMES } \\
\text { Characidae }\end{array}$ & & & & & & & & & & & & \\
\hline Deuterodon langei & Dlan & NUP9572 & 59 & 10.6 & 4.3 & 79.6 & 3.9 & $*$ & - & 0.4 & 1.3 & 0.09 \\
\hline Hollandichthys multifasciatus & Hmul & NUP9578 & 29 & 38.6 & 3.4 & 21.5 & 0.6 & 33.1 & - & - & 2.9 & 0.45 \\
\hline $\begin{array}{l}\text { Mimagoniates microlepis } \\
\text { Crenuchidae }\end{array}$ & Mmic & NUP9568 & 58 & 64.1 & 7.4 & 5.9 & 22.4 & 0.2 & - & - & - & 0.28 \\
\hline Characidium lanei & Clan & NUP9577 & 16 & 15.5 & - & - & 82.6 & 1.9 & - & - & - & 0.21 \\
\hline $\begin{array}{l}\text { Characidium pterostictum } \\
\text { CYPRINODONTIFORMES } \\
\text { Poeciliidae }\end{array}$ & Cpte & NUP9588 & 14 & - & - & 2.3 & 97.7 & - & - & - & - & 0.05 \\
\hline $\begin{array}{l}\text { Phalloceros harpagos } \\
\text { SILURIFORMES } \\
\text { Callichthyidae }\end{array}$ & Phar & NUP9527 & 20 & - & * & - & 7.4 & * & - & 5.6 & 87.0 & 0.08 \\
\hline $\begin{array}{l}\text { Scleromystax barbatus } \\
\text { Heptapteridae }\end{array}$ & Sbar & NUP9570 & 13 & - & * & - & $\mathbf{5 3 . 7}$ & 0.7 & - & 3.7 & 41.9 & 0.29 \\
\hline Acentronichthys leptos & Alep & NUP9592 & 13 & - & 4.6 & 2.3 & 92.9 & - & - & - & 0.3 & 0.05 \\
\hline Rhamdia quelen & Rque & NUP9524 & 28 & 23.6 & 0.6 & 26.0 & 0.8 & 41.7 & 7.2 & - & $*$ & 0.38 \\
\hline $\begin{array}{l}\text { Rhamdioglanis frenatus } \\
\text { Loricariidae }\end{array}$ & Rfre & NUP13614 & 6 & 11.5 & - & 13.0 & $*$ & 75.5 & - & - & - & 0.22 \\
\hline Ancistrus multispinnis & Amul & NUP13626 & 6 & - & - & - & - & $*$ & - & 4.4 & 95.6 & 0.05 \\
\hline Rineloricaria sp. & Rinsp & NUP10898 & 8 & $*$ & - & - & - & 0.3 & - & 1.9 & 97.8 & 0.02 \\
\hline Schizolecis guntherti & Sgun & NUP9581 & 25 & - & - & - & $*$ & $*$ & - & 3.4 & 96.6 & 0.02 \\
\hline $\begin{array}{l}\text { Schizolecis sp. } 1 \\
\text { SYNBRANCHIFORMES } \\
\text { Synbranchidae }\end{array}$ & Schsp1 & NUP10899 & 26 & - & - & - & * & 0.1 & - & 4.3 & 95.6 & 0.03 \\
\hline Synbranchus marmoratus & Smar & NUP9567 & 5 & 1.9 & 0.3 & 2.2 & 6.3 & 2.7 & 86.0 & - & 0.6 & 0.06 \\
\hline
\end{tabular}

represented by $P$. pappenheimi, $H$. multifasciatus and $S$. marmoratus. Terrestrial-insectivores included mainly adults of Hymenoptera and Coleoptera in their diets, and were characterized by M. microlepis in all sections and by $H$. multifasciatus in the headwaters and in the middle, but the latter changed to aquatic-invertivorous in the mouth. The last two groups showed the highest diet breadth indices $(B$ from 0.11 to 0.50 ) and ( $B$ from 0.02 to 0.49 ), respectively, indicating low feeding specialization compared to the detritivores and aquatic-insectivores. The omnivore guild occurred only in the headwaters, and was represented by Deuterodon langei $(B=0.25)$, which changed its diet and was among the herbivorous species in the other sections $(B$ from 0.09 to 0.10 ); while the piscivore guild, represented by $S$. marmoratus, was highly specialized $(B=0.06)$ and occurred only in the middle section. 
Table 3. cont. Systematic position, diet composition and breadth (Levin's index $\boldsymbol{B}$ ) of fish assemblage of the Vermelho River, East Atlantic basin, southern Brazil. Data are expressed as percentage volume of food items. Number of stomachs analyzed $(\mathrm{N}) ; *=$ Values $<0.1 \% ;-$ not recorded. Predominant items are in bold.

\begin{tabular}{|c|c|c|c|c|c|c|c|c|c|c|c|}
\hline & \multirow[b]{2}{*}{ Code } & \multirow[b]{2}{*}{ Voucher } & \multirow[b]{2}{*}{$\mathrm{N}$} & \multicolumn{3}{|c|}{ Allochthonous } & \multicolumn{3}{|c|}{ Autochthonous } & \multicolumn{2}{|l|}{ Undetermined } \\
\hline & & & & $\begin{array}{l}\text { Terrestrial } \\
\text { insect }\end{array}$ & $\begin{array}{c}\text { Other terrestrial } \\
\text { invertebrates }\end{array}$ & Plants & $\begin{array}{l}\text { Aquatic } \\
\text { insects }\end{array}$ & $\begin{array}{l}\text { Other aquatic } \\
\text { invertebrates }\end{array}$ & Fish Algae & Detritus/ & $B$ \\
\hline \multicolumn{12}{|l|}{ Mouth } \\
\hline $\begin{array}{l}\text { CHARACIFORMES } \\
\text { Characidae }\end{array}$ & & & & & & & & & & & \\
\hline Deuterodon langei & Dlan & NUP9579 & 11 & 18.8 & - & 79.1 & 0.6 & * & 1.3 & 0.1 & 0.10 \\
\hline Hollandichthys multifasciatus & Hmul & NUP9578 & 11 & 24.4 & 18.6 & 8.9 & $*$ & 48.0 & - & - & 0.50 \\
\hline $\begin{array}{l}\text { Mimagoniates microlepis } \\
\text { Crenuchidae }\end{array}$ & Mmic & NUP9576 & 36 & 65.1 & 4.4 & 3.4 & 26.8 & $*$ & - & 0.3 & 0.20 \\
\hline Characidium lanei & Clan & NUP9582 & 10 & - & - & 0.3 & 94.8 & 3.3 & - & 1.6 & 0.04 \\
\hline $\begin{array}{l}\text { Characidium pterostictum } \\
\text { CYPRINODONTIFORMES } \\
\text { Poeciliidae }\end{array}$ & Cpte & NUP9588 & 11 & - & - & - & 99.7 & 0.3 & - & - & 0.01 \\
\hline $\begin{array}{l}\text { Phalloceros harpagos } \\
\text { SILURIFORMES } \\
\text { Callichthyidae }\end{array}$ & Phar & NUP9587 & 5 & - & - & - & - & - & $\begin{array}{l}-\quad 15.7 \\
-15\end{array}$ & 84.3 & 0.36 \\
\hline $\begin{array}{l}\text { Scleromystax barbatus } \\
\text { Heptapteridae }\end{array}$ & Sbar & NUP10905 & 13 & - & * & 7.0 & 41.4 & 0.5 & 0.3 & 50.6 & 0.26 \\
\hline $\begin{array}{l}\text { Pimelodella pappenheimi } \\
\text { Loricariidae }\end{array}$ & Ppap & NUP13613 & 7 & 0.3 & - & 2.0 & 24.3 & 73.1 & - & 0.4 & 0.17 \\
\hline Kronichthys cf. lacerta & Klac & NUP10900 & 11 & - & - & - & - & - & 5.2 & 94.8 & 0.11 \\
\hline Pseudotothyris obtusa & Pobt & NUP10902 & 31 & - & - & - & 0.1 & 0.9 & 1.9 & 97.1 & 0.02 \\
\hline Rineloricaria sp. & Rinsp & NUP10898 & 5 & - & - & - & 1.8 & - & 6.4 & 91.8 & 0.09 \\
\hline Schizolecis guntherti & Sgun & NUP9585 & 5 & - & - & - & - & - & 0.7 & 99.3 & 0.01 \\
\hline $\begin{array}{l}\text { Schizolecis } \text { sp. } \\
\text { SYNBRANCHIFORMES } \\
\text { Synbranchidae }\end{array}$ & Schsp & NUP10903 & 23 & - & - & - & - & $*$ & 6.3 & 93.7 & 0.07 \\
\hline Synbranchus marmoratus & Smar & NUP9567 & 13 & - & 0.3 & - & 2.4 & 77.3 & $19.3-$ & 0.8 & 0.14 \\
\hline
\end{tabular}

Differences in the average $B$ between guilds were significant $\left(\mathrm{F}_{4.34}=4.7, \mathrm{p}<0.01\right)$. A multiple pair-wise test (LSD test, $\mathrm{p}<0.05$ ) indicated that the the detritivore and aquaticinsectivore guilds had significantly lower $B$ values than the other guilds (Fig. 4). When analyzing the diet breadth along the gradient for each guild, the highest B values were found in the middle for aquatic- and terrestrial-insectivores and aquatic-invertivores and in the mouth for detritivores, but there was no evidence of longitudinal increases in trophic specialization of these guilds, except a slight increase in this parameter for aquatic-insectivores (Fig. 5).

\section{Trophic guild distribution}

The species composition of the trophic guilds was significantly related to the stream section $\left(\chi^{2}=54.9, \mathrm{gl}=12\right.$, $\mathrm{p}<0.01)$. The increase in the number of detritivorous species and the reduction in terrestrial- and aquatic-insectivores from the headwaters to the mouth contributed to this association (compare Fig. 3).

Both density and biomass of invertivores and aquaticinsectivores decreased along the gradient, while the density of terrestrial-insectivores and the density and biomass of detritivores increased (Fig. 6). The density of aquaticinsectivores predominated in the headwaters and in the middle, while terrestrial-insectivores predominated in the mouth section, followed by detritivorous species (Fig. 6a). The biomass of aquatic-invertivores predominated in all sections, but with a clear decrease along the gradient (Fig. 6b).
The species composition (\%) of detritivores was positively correlated $(\mathrm{p}<0.01)$ with the PCA1 scores, indicating a longitudinal increase associated with the increase in depth, channel width, and substrates such as trunks/branches and sand/clay. On the other hand, terrestrial- and aquaticinsectivores were negatively correlated with the PCA1 scores; the latter correlation was statistically significant $(p<0.01)$, showing that the higher frequencies of aquatic-insectivores were related to environments with greater flow and rocky substrate (headwaters and middle), whereas aquaticinvertivores did not show a significant correlation with the environmental gradient (Fig. 7).

\section{Discussion}

The analysis of physical and chemical variables revealed a clear environmental gradient from the headwaters to the mouth of the Vermelho River. This probably occurs because streams of the Atlantic coast have a steep slope, rising at high altitudes and reaching the coastal plain within a few kilometers. This implies a high environmental variability, and that these environments can be used to draw ecological inferences based on their longitudinal gradient.

Following a longitudinal model, the sources of the resources exploited by fish differed spatially along the course of the Vermelho River. The decrease in the use of allochthonous resources and the increase of autochthonous resources downstream (toward the mouth) was the first 

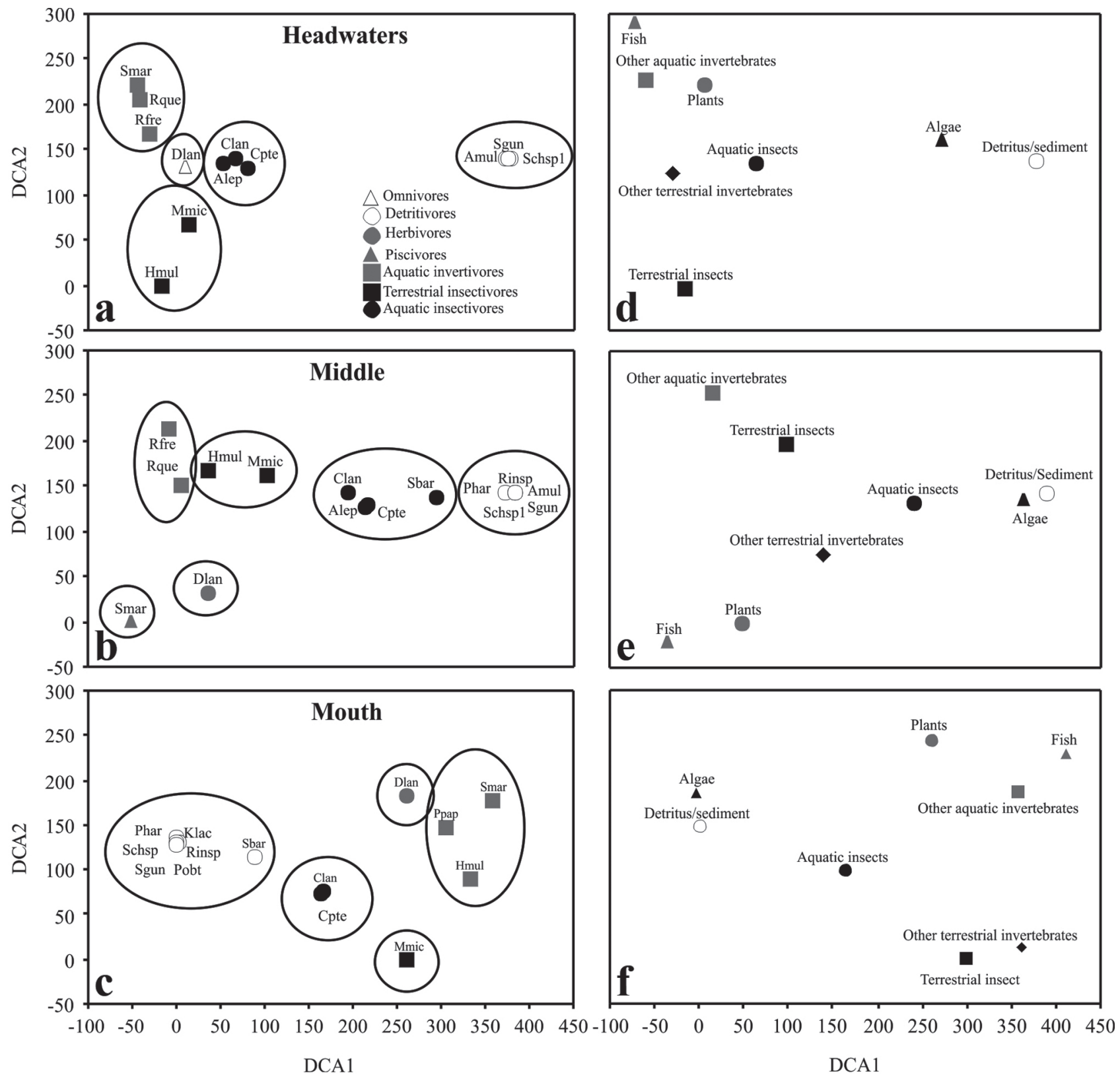

Fig. 3. Ordination of fish species in the respective trophic guilds $(\mathbf{a}, \mathbf{b}, \mathbf{c})$ and food items $(\mathbf{d}, \mathbf{e}, \mathbf{f})$ along the longitudinal gradient of the Vermelho River, East Atlantic basin, Antonina, Paraná State, Brazil. Circles represent species belonging to the same trophic guild. Codes according to Table 3 .

longitudinal pattern, and showed that the diet fish were induced by the local supply of food resources. The dense vegetation cover at the headwaters may have increased the input of allochthonous food, which apparently became the major energy resource for some species in this section. According to Lowe-McConnell (1999), the canopy produced by riparian vegetation limits primary production, and fish might become dependent on resources from terrestrial ecosystems.
Specific changes in the exploitation of resources along the gradient, as observed for D. langei, H. multifasciatus, Synbranchus marmoratus and Scleromystax barbatus, also indicated that the assemblage responded at the species level to spatial changes in the resource supply. Deuterodon lange $i$ and $H$. multifasciatus consumed larger amounts of terrestrial insects in the headwaters, where the supply of this resource is presumably higher due to the greater interface between the aquatic and terrestrial ecosystems and the higher canopy 


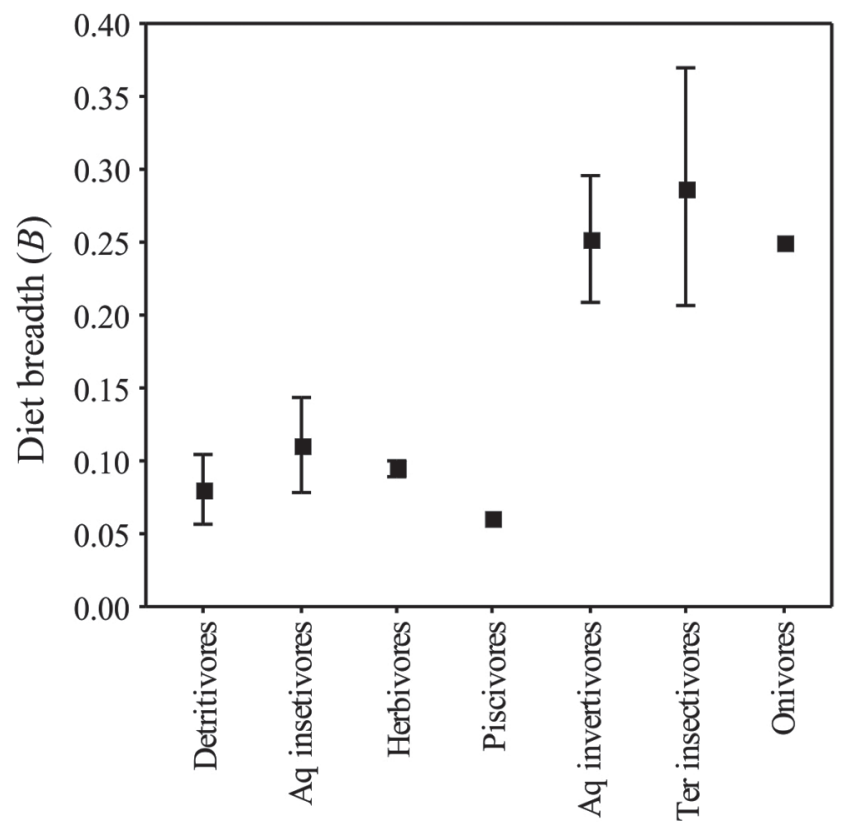

Fig. 4. Mean \pm standard error of diet breadth $(B)$ of fish trophic guilds in the Vermelho River, East Atlantic basin, Antonina, Paraná State, Brazil. Aq = aquatic; ter = terrestrial. Piscivores and omnivores are not included in the ANOVA.

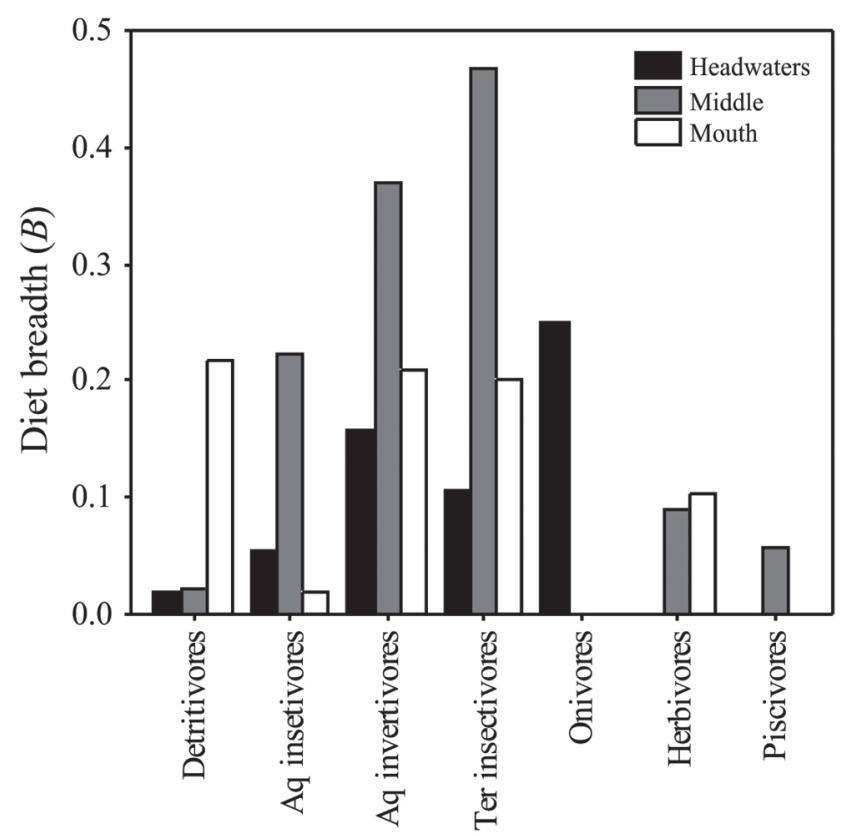

Fig. 5. Longitudinal niche breadth ( $B$ values) of each fish trophic guild in the Vermelho River, East Atlantic basin, Antonina, Paraná State, Brazil. Aq = aquatic; ter = terrestrial.

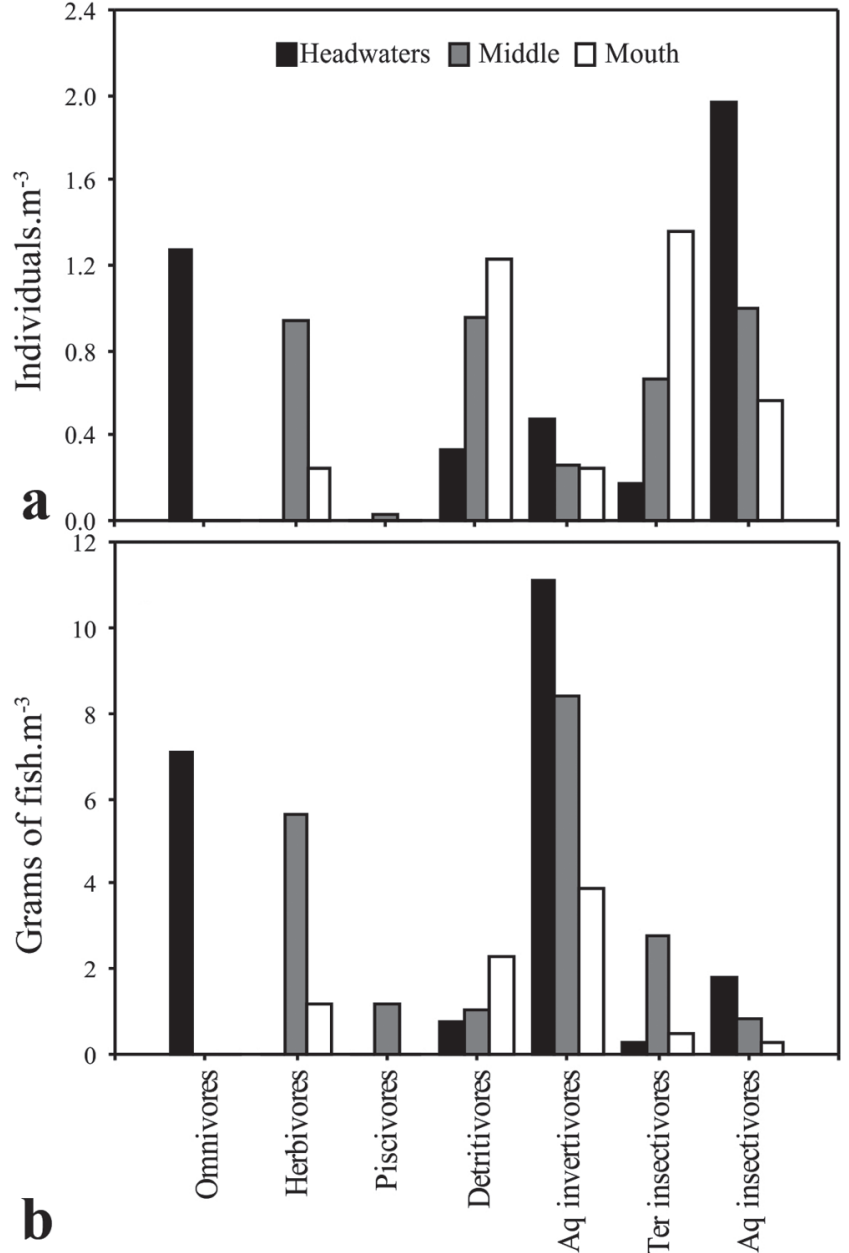

Fig. 6. Density (a) and biomass (b) of trophic guilds along the longitudinal gradient of the Vermelho River, East Atlantic basin, Antonina, Paraná State, Brazil. Aq = aquatic; ter $=$ terrestrial.

(Vannote et al., 1980; Peres-Neto et al., 1995; Esteves \& Aranha, 1999; Rezende \& Mazzoni, 2006). H. multifasciatus fed predominantly on shrimp at the mouth, where they were abundant (pers. obs.). Similarly, S. marmoratus seems to have responded to the spatial availability of resources, since in the headwaters it fed mainly on Aegla sp., a freshwater crab that is abundant in riffles (Kikuchi \& Uieda, 1998); while in the middle section this species changed its diet to fish $(D$. langei), which is present in high density in this section; and in the mouth consumed predominantly shrimp. With respect to $S$. barbatus, we infer that a possible downstream decrease in the supply of aquatic insects such as Ephemeroptera and Trichoptera, which are frequent upstream (Vannote et al., 1980; Bispo et al., 2006), influenced its change from an aquaticinsectivore in the middle to a detritivore in the mouth.

Considering the number of trophic guilds, the middle was the most diverse section with six of the seven guilds present, 

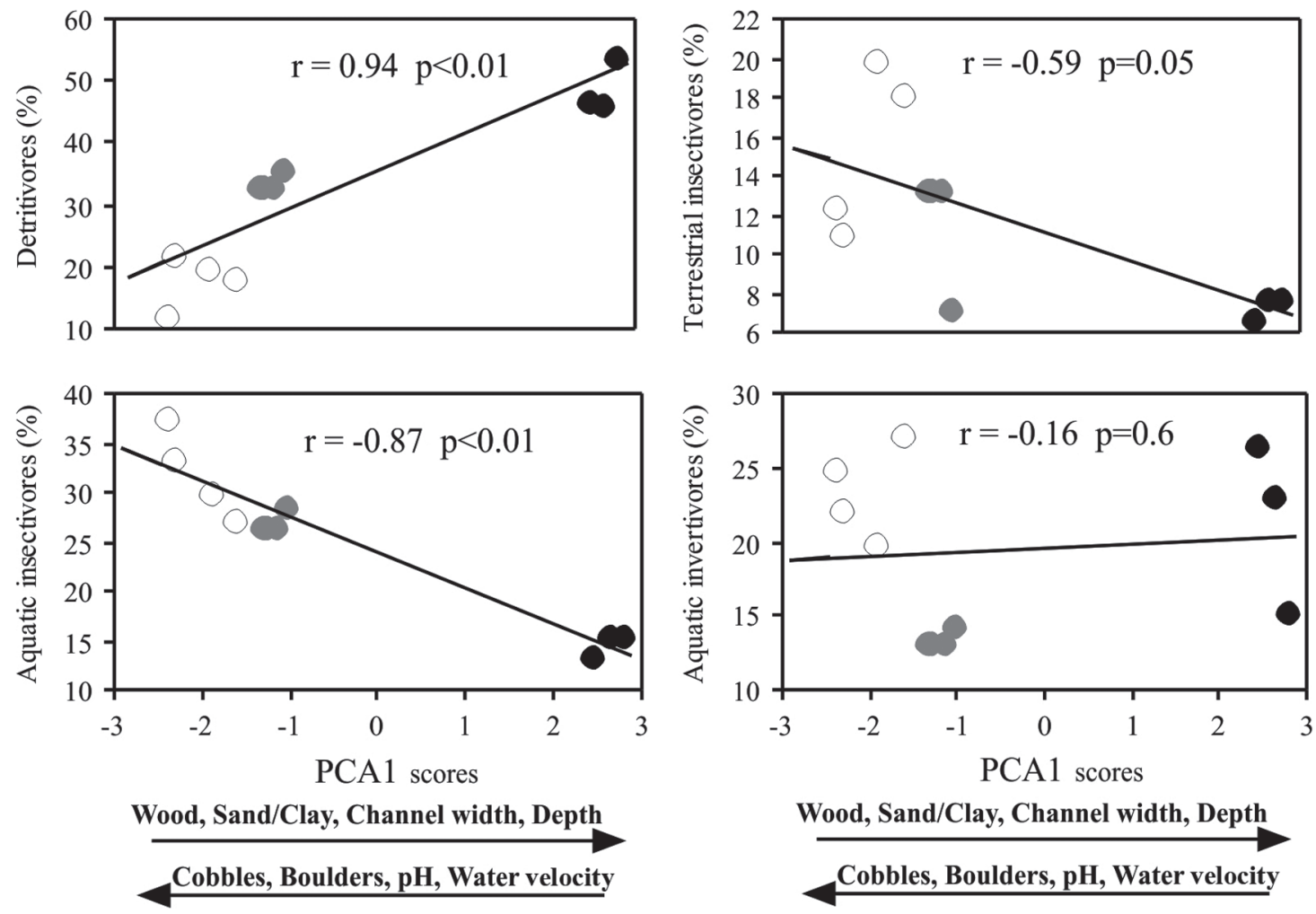

Fig. 7. Spearman correlations between the distribution (percentage frequency) of guilds and scores of the first axis of the principal components analysis (PCA1) applied to the correlation matrix of abiotic variables. White circle = headwaters; gray circle $=$ middle stretch; and black circle $=$ mouth of the Vermelho River, East Atlantic basin, Antonina, Paraná State, Brazil.

coinciding with the highest richness and diversity (unpublished data). In the context of the longitudinal gradient, transitional environments such as the middle section may have high heterogeneity and greater availability of different types of food resources, thus allowing more species to coexist and form distinct guilds. In more heterogeneous locations, one of the major mechanisms of trophic segregation, and consequently of species coexistence, is the partitioning of feeding resources (Ross, 1986).

Detritivorous species significantly increased along the gradient, due to the increase in the relative number of armored catfishes (Loricariidae), which doubled in the mouth. The longitudinal success of this guild was also evidenced by the high biomass and density of its species, despite their small body size, in this section. Trophic specializations of Neotropical detritivores include a longer intestine (Fugi et al., 2001), which according to Bowen (1983) is necessary for adequate adsorption of slow-digesting foods from detritus. Along with the apparent greater availability of organic detritus downstream, detritivorous species also seemed to be favored by the longitudinal increase on primary productivity, because a higher proportion of them fed on benthic algae.

The relatively small number of aquatic-insectivorous species downstream was related to the absence of $A$. leptos in the catches, as well as to the change of guild of S. barbatus to detritivorous in the mouth section, influencing the longitudinal decrease of this guild in density and biomass. However, in the mouth the considerable decrease in the catch of $C$. lanei and C. pterostictum, which have morphological adaptations (e.g., extended fins) for anchoring and picking larvae of aquatic insects on the rocky bottom (Casatti \& Castro, 2006), was decisive for the longitudinal decrease of this guild. On the other hand, the change of guild of $H$. multifasciatus to aquatic-invertivore in the mouth was reflected in the reduction of terrestrial insectivores in this section. Nevertheless, the density of this guild increased progressively from the headwaters to the mouth due to the relatively high catch of juveniles of M. microlepis, especially in the mouth section. These results corroborate the suggestion of Braga et al. (2012) that juvenile stages of this species move downstream.

Environmental variations including the longitudinal increase in depth and in the amount of sandy substrate downstream favored the expansion of detritivorous species. Nevertheless, the reduction of flow and decrease of rocky substrate downstream appear to have determined the relative decrease of aquatic- and terrestrial-insectivores. Therefore, although there was no evidence of a longitudinal increase 
in specialization of the guilds, the longitudinal gradient of the Vermelho River resulted in some proportional changes in the guild composition. The longitudinal decrease in the number of species of terrestrial-insectivores, which was the most generalist guild (highest $B$ values) and the relative increase in the number of species of detritivores (the most specialized) probably reflects the considerable longitudinal changes in the trophic relationships in this system. In addition, the longitudinal increase in specialization of the characin D. langei (passing from omnivorous in the headwaters to a primarily herbivorous specialist in the middle and mouth) and the slight longitudinal increase in specialization among the aquatic-insectivores seem to agree with the hypothesis of a more-specialized fish assemblage downstream.

These changes in the species composition of trophic guilds were probably influenced by the longitudinal variations of environmental parameters, and agree with the results of Pouilly et al. (2006), in streams of the Eastern Andean slope, who observed a high proportion of detritivores, algivores and piscivores (more-specialized guilds) at lower altitudes. For tropical streams with a lower gradient, these results also concord with those of Angermeier \& Karr (1983), who observed an increase in the density of algivores and herbivores and a reduction in aquatic-insectivores with an increase in stream order in Panama.

Therefore, the possible processes that allow us to interpret these results in accordance with the RCC were: (i) increase from the headwaters to the mouth in the availability of fine organic matter (e.g., detritus, probably fragmented by the upstream benthic community and by hydrological action) and of benthic algae, which contributed to increase the proportion of detritivores downstream; (ii) downward trend in the supply of aquatic insects such as Ephemeroptera and Trichoptera as a consequence of the lower hydrodynamics and availability of rocky substrates downstream, resulting in a decrease in the relative proportion of aquatic-insectivores; and (iii) downward trend toward the mouth in the supply of terrestrial insects, as a likely result of reduction in vegetation cover, followed by a relative decrease of terrestrial-insectivores.

In this context, the supply of food resources to the fish fauna may change rapidly from the headwaters to the mouth, and modify the diet composition and the longitudinal distribution of trophic guilds. Given these considerations, a new alternative emerges to discuss the trophic mechanisms structuring fish communities in streams of the Brazilian Atlantic coast, because our results mirrored the patterns of food resource availability predicted by the RCC. These results revealed changes in feeding habits at the species level, as well as a proportional change in the longitudinal composition of guilds, such as the transition from insectivorous species (especially terrestrial-insectivores) with a more-diversified diet in the headwaters to detritivorous species (more specialized) in the mouth section, which may have been associated with changes in the longitudinal availability of food resources.

\section{Acknowledgments}

The authors are grateful to $\mathrm{CNPq}$ for the doctoral scholarship and to CAPES for the sandwich-doctoral scholarship granted to Luciano L. Wolff. To Nupélia and PEA for providing the infrastructure. To the SPVS (Sociedade de Pesquisa em Vida Selvagem e Educação Ambiental - Society for Wildlife Research and Environmental Education) for permission and support in the conduct of this study in the Reserva Morro da Mina. We are also grateful to our colleagues Thiago Ewerton Vecchi, Dilermando Pereira Lima Junior, Carlos Alexandre Miranda and Cristiano Marcondes Pereira for helping in the sampling, and to Javier Lobón-Cerviá for suggestions. The English was revised by Janet W. Reid (JWR Associates).

\section{Literature Cited}

Abelha, M. C. F., A. A. Agostinho \& E. Goulart. 2001. Plasticidade trófica em peixes de água doce. Acta Scientiarum, Biological Sciences, 23: 425-434.

Abilhoa, V., H. Bornatowski \& G. Otto. 2009. Temporal and ontogenetic variations in feeding habits of Hollandichthys multifasciatus (Teleostei: Characidae) in coastal Atlantic rainforest streams, southern Brazil. Neotropical Ichthyology, 7: 415-420.

Allan, J. D. 1995. Stream ecology: structure and function of running waters. Boundary Row, London, Chapman \& Hall.

Angermeier, P. L. \& J. R. Karr. 1983. Fish communities along environmental gradients in a system of tropical streams. Environmental Biology of Fishes, 9: 117-135.

Aranha J. M. R. \& E. P. Caramaschi. 1999. Estrutura populacional, aspectos da reprodução e alimentação dos Cyprinodontiformes (Osteichthyes) de um riacho do sudeste do Brasil. Revista Brasileira de Zoologia, 16: 637-651.

Bispo, P. C., L. G. Oliveira, L. M. Bini \& K. G. Sousa. 2006. Ephemeroptera, Plecoptera and Trichoptera assemblages from riffles in mountain streams of Central Brazil: environmental factors influencing the distribution and abundance of immatures. Brazilian Journal of Biology, 66: 611-622.

Bowen, S. H. 1983. Detrivory in neotropical fish communities. Environmental Biology of Fishes, 9: 137-144.

Braga, R. R., M. R. Braga \& J. R. S. Vitule. 2012. Population structure and reproduction of Mimagoniates microlepis with a new hypothesis of ontogenetic migration: implications for stream fish conservation in the Neotropics. Environmental Biology of Fishes, 94: 1-11.

Brenden, T. O., L. Z. Wang \& P. W. Seelbach. 2008. A river valley segment classication of Michigan streams based on sh and physical attributes. Transactions of the American Fisheries Society, 137: 1621-1636.

Casatti, L. \& R. M. C. Castro. 2006. Testing the ecomorphological hypothesis in a headwater riffles fish assemblage of the rio São Francisco, southeastern Brazil. Neotropical Ichthyology, 4: 203-214.

Esteves, K. E. \& J. M. R. Aranha 1999. Ecologia trófica de peixes de riachos. Pp. 157-182. In: Caramaschi, E. P., R. Mazzoni \& P. R. Peres-Neto. (Eds.). Ecologia de peixes de riachos. Série Oecologia Brasiliensis, Rio de Janeiro.

Ferreira, F. C. \& M. Petrere Jr. 2009. The sh zonation of the Itanhaém river basin in the Atlantic Forest of southeast Brazil. Hydrobiologia, 363: 11-34. 
Fugi, R., A. A. Agostinho \& N. S. Hahn. 2001. Trophic morphology of five benthic-feeding fish species of a tropical floodplain. Brazilian Journal of Biology, 61: 27-33.

Gordon, N. D., T. A. Mcmahon \& B. L. Finlayson. 1992. Stream hydrology: an introduction for ecologists. Chichester, John Wiley $\&$ Sons.

Hammer, Ø., D. A. T. Harper \& P. D. Ryan. 2001. PAST: Paleontological Statistics Software package for education and data analysis. Palaeontologia Electronica, 4: 1-9.

Hellawell, J. M. \& R. Abel. 1971. A rapid volumetric method for the analysis of the food of fishes. Journal of Fish Biology, 3: 29-37.

Hill, M. O. \& H. G. Gauch Jr. 1980. Detrended correspondence analysis: an improved ordination technique. Vegetation, 42: 4758.

Hurlbert, S. H. 1978. The measurement of niche overlap and some relatives. Ecology, 59: 67-77.

Hyslop, E. J. 1980. Stomach contents analysis: a review of methods and their applications. Journal of Fish Biology, 17: 411-429.

Ibañez, C., T. Oberdorff, G. Teugels, V. Mamononekene, S. Lavoué, Y. Fermon, P. Paugy \& A. Kamdem-Toham. 2007. Fish assemblages structure and function along environmental gradients in rivers of Gabon (Africa). Ecology of Freshwater Fish, 16: 315-334.

Junk, W. J., P. B. Bayley \& R. E. Sparks. 1989. The flood pulse concept in river-floodplain systems. Canadian Journal of Fisheries and Aquatic Sciences, 106: 110-127.

Kikuchi, R. M. \& V. S. Uieda. 1998. Composição da comunidade de invertebrados de um ambiente lótico tropical e sua variação espacial e temporal. Pp. 157-173. In: Nessimian, J. L. \& A. L. Carvalho (Eds). Ecologia de insetos aquáticos. Série Oecologia Brasiliensis, Rio de Janeiro.

Lowe-McConnell, R. H. 1999. Estudos ecológicos de comunidade de peixes tropicais. São Paulo, Edusp.

Maack, R. 1981. Geografia física do estado do Paraná. Rio de Janeiro, J. Olympio.

Mazzoni, R., M. Moraes, C. F. Rezende \& R. Iglesias-Rios. 2010. Diet and feeding daily rhythm of Pimelodella lateristriga (Osteichthyes, Siluriformes) in a coastal stream from Serra do Mar-RJ. Brazilian Journal of Biology, 70: 1123-1129.

Mazzoni, R. \& C. F. Rezende. 2003. Seasonal diet shift in a Tetragonopterinae (Osteichthyes, Characidae) from the Ubatiba River, RJ, Brazil. Brazilian Journal of Biology, 63: 69-74.

Melles, S. J., N. E. Jones \& B. Schmidt. 2012. Review of theoretical developments in stream ecology and their inuence on stream classication and conservation planning. Freshwater Biology, 57: 415-434.

Oberdorff, T., E. Guilbert \& J. C. Luchetta. 1993. Patterns of sh species richness in the Seine River basin, France. Hydrobiologia, 259: 157-167.
Peres-Neto, P. R., C. R. S. F. Bizerril \& R. Iglesias. 1995. An overview of some aspects of river ecology: a case study on fish assemblages distribution in an eastern Brazilian coastal river. Pp. 317-334. In: Esteves, F. A. (Ed.). Estrutura, funcionamento e manejo de ecossistemas brasileiros. Série Oecologia Brasiliensis, Rio de Janeiro.

Petry, A. C. \& U. H. Schulz, 2006. Longitudinal changes and indicator species of the sh fauna in the subtropical Sinos River, Brazil. Journal of Fish Biology, 69: 272-290.

Poole, G. C. 2002. Fluvial landscape ecology: addressing uniqueness within the river discontinuum. Freshwater Biology, 47: 641660.

Pouilly, M., S. Barrera \& C. Rosales. 2006. Changes of taxonomic and trophic structure of sh assemblages along an environmental gradient in the Upper Beni watershed (Bolivia). Journal of Fish Biology, 68: 137-156.

Rezende, C. F. \& R. Mazzoni. 2006. Disponibilidade e uso de recursos alóctones por Bryconamericus microcephalus (Miranda-Ribeiro) (Actinopterygii, Characidae), no córrego Andorinha, Ilha Grande, Rio de Janeiro, Brasil. Revista Brasileira de Zoologia, 23: 218-222.

Rice, S. P., M. T. Greenwood \& C. B. Joyce. 2001. Tributaries, sediment sources, and the longitudinal organisation of macroinvertebrate fauna along river systems. Canadian Journal of Fisheries and Aquatic Sciences, 58: 824-840.

Ross, S. T. 1986. Resource partitioning in fish assemblages: a review of field studies. Copeia, 1986: 352-388.

Schlosser, I. J. 1982. Fish community structure and function along two habitat gradients in a headwater stream. Ecological Monographs, 52: 395-414.

Statzner, B. \& B. Higler. 1986. Stream hydraulics as a major determinant of benthic invertebrate zonation patterns. Freshwater Biology, 16: 127-139.

Vannote, R. L., G. W. Minshall, K. W. Cummings, J. R. Sedell \& C. E. Cushing. 1980. The River Continuum Concept. Canadian Journal of Fisheries and Aquatic Sciences, 37: 130-137.

Velloso, H. P., A. L. R. Rangel-Filho \& J. C. A. Lima. 1991. Classificação da vegetação brasileira adaptada a um sistema universal. Rio de Janeiro, Instituto Brasileiro de Geografia e Estatística - Departamento de Recursos Naturais e Estudos Ambientais.

Zar, J. H. 1999. Biostatistical analysis. New Jersey, Prentice-Hall, Inc..

Ward, J. V. 1989. The four-dimensional nature of lotic ecosystems. Journal of the North American Benthological Society, 8: 2-8.

Submitted August 9, 2012 Accepted March 20, 2013 by Francisco Gerson Araujo Published June 28, 2013 